\title{
STATUS OF PESTICIDE CONTAMINATION IN KAYAMKULAM ESTUARY WITH SPECIAL REFERENCE TO FISHES
}

\author{
B. Moly \& S. Amina \\ Research Department of Zoology \\ S.D. College, University of Kerala, Alappuzha, Kerala, India. \\ Corresponding author : molyshajith6@gmail.com
}

\begin{abstract}
World wide application of pesticide has drastically increased during the last two decades resulting with the changes in farming practices and enormously increasing intensive agriculture. This wide application of pesticides has resulted in the presence of their residues in various environmental matrices. It's environmental tenacious, hoarding and their impacts in the ecosystem was incompetently perceive. These chemicals will finally enters into the aquatic system. Their lower persistent and soluble nature of many pesticide will impart their major portion to fishes, so the aim of the present study was the assessment of residues in water and fishes of the aquatic system it will throw back the present status of accumulation pesticides in the ecosystem. Result of the analysis showed that the fishes from the various study locations are fit for domestic consumptions, as the samples studied did not indicate any adverse or extremely high pesticide content that may affect the health of those consuming the fishes.
\end{abstract}

\section{INTRODUCTION}

Pesticides are the substance or mixture of substances conscious for preventing, destroying, or controlling any pest, including vectors of human or animal disease, unwanted species of plants or animals, causing harm and interfering with the production, processing, storage, transport, or marketing of food, agricultural commodities, wood and wood products or animal feedstuffs, or substances that may be applied to the animals for the control of insects, arachnids, or other pests in or on their bodies (FAO). Pesticides can enter into the surface water through runoff from treated plants and soil. Nowadays Pollution of aquatic ecosystems by extensive and indiscriminate use of toxic chemicals by drift, runoff, drainage and leaching ${ }^{1}$ forms one of the serious problems worldwide.
Enormous chemical applied to the environment aiming at target organism, very easily reach and affect non target organisms including humans ${ }^{2}$. Three million workers in the developing countries experiences hazardous poisoning from pesticides every year and about 18000 die. High percentage populations of developing countries mainly involved in agriculture, their insufficient or non- existence health criteria can be limited their safe use of pesticides, which leads to the easy way of pesticides entry into human beings.

In India, the concentration of these pesticides have been detected in almost all segment of environment due to their extensive use in past, which have shown potential to biomagnified in animal tissue, blood adipose tissue and breast milk ${ }^{3}$. Since the pesticides are lipid soluble in nature, 
cumulative accumulation of low concentration of these in the body of mammals might pose potential hazards in long run. Many more recent works have indicated that the presence of OC residues in surface waters, sediments, biota and vegetations ${ }^{4}$. The tenacious nature of organochlorine residues in the environment may pose the problem of chronic toxicity to animals and humans.

\section{MATERIALS AND METHODS}

\section{Study Area}

Kayamkulam Kayal lies between latitudes $9^{\circ} 2^{\prime} \mathrm{N}$ and $9^{\circ} 16^{\prime} \mathrm{N}$ and longitudes $76^{\circ} 25^{\prime} \mathrm{E}$ and $76^{\circ} 32^{\prime} \mathrm{E}$. Kayamkulam Estuary is a shallow brackish water lagoon streaching between Panmana and Karthikapall, it has an outlet to the Arabian sea at Kayamkulam barrage.

\section{Pesticide Analysis in Water Sample}

Surface water and fish samples were collected from August 2014 -January 2015 at monthly intervals. Surface water samples were collected using clean plastic bottles and preserved at $4^{\circ} \mathrm{c}$. In the laboratory, using liquid-liquid extraction (LLE) as described in APHA (2005) the total amount of each surface water sample $(800 \mathrm{ml})$ was filtered with Whatman filter paper (i.d. $70 \mathrm{~mm}$ ) to remove debris and suspended materials and then poured into a 2 liter separator funnel. For the first LLE, the mixture of $100 \mathrm{ml} \mathrm{n}$ hexane and dichloromethane $(1: 1 \mathrm{v} / \mathrm{v})$ was added and shaken vigorously for $2 \mathrm{~min}$ before two phase separation. The water-

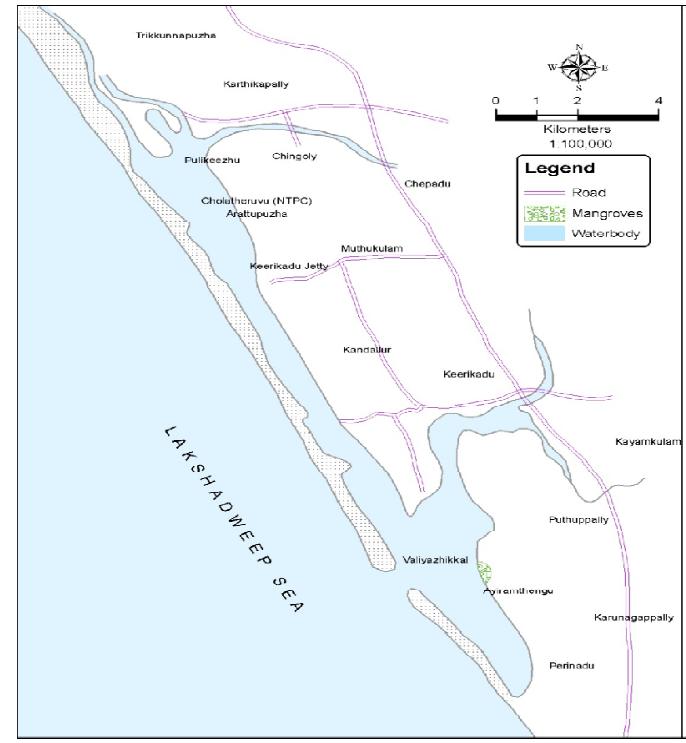

Fig.1 Map showing Kayamkulam Estuary

phase was drained from the separator funnel into a $1000 \mathrm{ml}$ beaker. The organic-phase was carefully spilled into a glass funnel containing $20 \mathrm{~g}$ of anhydrous sodium sulfate through a $200 \mathrm{ml}$ concentrator tube. Following the second and third LLE, the water-phase was poured back into the separator funnel to re-extract with $50 \mathrm{ml}$ of the same solvent mixture. The extract was concentrated to the volume of $2 \mathrm{ml}$ under a gentle stream of nitrogen using rotary evaporator and then assessed with Gas Chromatography with micro Electron Capture Detector (GC-iECD) (Siriwong et al., 2009 ).

\section{Pesticide Analysis in Fish Sample}

The commonly available fishes like Liza parsia and Etroplus suratensiswere selected for the study. Fishes were collected during 2014 August - 2015 January with 
the help of local fisherman from four main stations of Kayamkulam backwater mainly Ayiramthengu, Valiazheekal, Kochiyude jetty, Choolatheruvu. Healthy fishes of length 15 to $20 \mathrm{~cm}$ and weight 95 to 115 gms were selected for the study. Fishes were transported to the laboratory for the analysis. Fishes were carefully dissected and removed gills, liver and muscle, then cleaned and stored under chilled condition at $20^{\circ} \mathrm{c}$ till the further processing. The samples were analysed for $\mathrm{HCH}$, aldrin and deldrin, endosulphan, DDT, 2,4-D, chloropyrifos, malathion and monocrotophos residues using GCMS following the official method (AOAC, 2012).

\section{RESULTS AND DISCUSSIONS}

Table 1 Showing pesticide load in water sample- site 1: Ayiramthengu

\begin{tabular}{|l|c|c|c|c|c|c|}
\hline Pesticides & Aug & Sep & Oct & Nov & Dec & Jan \\
\hline HCH & BDL & BDL & BDL & BDL & BDL & BDL \\
\hline Aldrin & BDL & BDL & BDL & BDL & BDL & BDL \\
\hline Endosulfan & BDL & BDL & BDL & BDL & BDL & BDL \\
\hline DDT & BDL & BDL & BDL & BDL & BDL & BDL \\
\hline 2,4 D & BDL & 0.00006 & 0.00008 & BDL & BDL & BDL \\
\hline Chlorpyrifos & BDL & BDL & BDL & BDL & BDL & BDL \\
\hline Monocrotophos & BDL & BDL & BDL & BDL & BDL & BDL \\
\hline
\end{tabular}

Table 2 Showing pesticide load in water-site 2: Valiyazheekal

\begin{tabular}{|l|c|c|c|c|c|c|}
\hline Pesticides & Aug & Sep & Oct & Nov & Dec & Jan \\
\hline HCH & BDL & BDL & BDL & BDL & BDL & BDL \\
\hline Aldrin & BDL & BDL & BDL & BDL & BDL & BDL \\
\hline Endosulfan & BDL & BDL & BDL & BDL & BDL & BDL \\
\hline DDT & BDL & BDL & BDL & BDL & BDL & BDL \\
\hline 2,4 D & BDL & BDL & BDL & BDL & BDL & BDL \\
\hline Chlorpyrifos & BDL & BDL & BDL & BDL & BDL & BDL \\
\hline Monocrotophos & BDL & BDL & BDL & BDL & BDL & BDL \\
\hline
\end{tabular}


Table 3 Showing pesticide load in water- site 3: Kochiyude Jetty

\begin{tabular}{|l|c|c|c|c|c|c|}
\hline Pesticides & Aug & Sep & Oct & Nov & Dec & Jan \\
\hline HCH & BDL & BDL & BDL & BDL & BDL & BDL \\
\hline Aldrin & BDL & BDL & BDL & BDL & BDL & BDL \\
\hline Endosulfan & BDL & BDL & BDL & BDL & BDL & BDL \\
\hline DDT & BDL & BDL & BDL & BDL & BDL & BDL \\
\hline 2,4 D & BDL & BDL & BDL & BDL & BDL & BDL \\
\hline Chlorpyrifos & BDL & BDL & BDL & BDL & BDL & BDL \\
\hline Monocrotophos & BDL & BDL & BDL & BDL & BDL & BDL \\
\hline
\end{tabular}

Table 4 Showing pesticide load in water- site 4: Choolatheruvu

\begin{tabular}{|l|c|c|c|c|c|c|}
\hline Pesticides & Aug & Sep & Oct & Nov & Dec & Jan \\
\hline HCH & BDL & BDL & BDL & BDL & BDL & BDL \\
\hline Aldrin & BDL & BDL & BDL & BDL & BDL & BDL \\
\hline Endosulfan & BDL & BDL & BDL & BDL & BDL & BDL \\
\hline DDT & BDL & BDL & BDL & BDL & BDL & BDL \\
\hline 2,4 D & BDL & BDL & BDL & BDL & BDL & BDL \\
\hline Chlorpyrifos & BDL & BDL & BDL & BDL & BDL & BDL \\
\hline Monocrotophos & BDL & 0.00006 & 0.00008 & BDL & BDL & BDL \\
\hline
\end{tabular}


Table 2.5 Showing pesticide content in Gills, Liver and Muscles of fish sample Liza parsia

\begin{tabular}{|l|c|c|c|c|c|c|c|c|c|c|c|c|c|c|c|c|c|c|}
\hline Pesticides & \multicolumn{3}{|c|}{ August } & \multicolumn{2}{|l|}{ September } & \multicolumn{2}{|l|}{ October } & \multicolumn{1}{l|}{ November } & \multicolumn{2}{l|}{ December } & \multicolumn{3}{|c|}{ January } \\
\hline HCH & G & L & M & G & L & M & G & L & M & G & L & M & G & L & M & G & L & M \\
\hline & ND & ND & ND & ND & ND & ND & ND & ND & ND & ND & ND & ND & ND & ND & ND & ND & ND & ND \\
\hline Aldrin & ND & ND & ND & ND & ND & ND & ND & ND & ND & ND & ND & ND & ND & ND & ND & ND & ND & ND \\
\hline Endosulfan & ND & ND & ND & ND & ND & ND & ND & ND & ND & ND & ND & ND & ND & ND & ND & ND & ND & ND \\
\hline DDT & ND & ND & ND & ND & ND & ND & ND & ND & ND & ND & ND & ND & ND & ND & ND & ND & ND & ND \\
\hline 2,4 D & ND & ND & ND & ND & ND & ND & ND & ND & ND & ND & ND & ND & ND & ND & ND & ND & ND & ND \\
\hline Chloropyrifos & ND & ND & ND & ND & ND & ND & ND & ND & ND & ND & ND & ND & ND & ND & ND & ND & ND & ND \\
\hline Monocrotophos & ND & ND & ND & ND & ND & ND & ND & ND & ND & ND & ND & ND & ND & ND & ND & ND & ND & ND \\
\hline
\end{tabular}

Table 2.6 Showing pesticide content in Gills, Liver and Muscles of fish sample Etroplus suratensis

\begin{tabular}{|c|c|c|c|c|c|c|c|c|c|c|c|c|c|c|c|c|c|c|}
\hline Pesticides & \multicolumn{3}{|c|}{ August } & \multicolumn{3}{|c|}{ September } & \multicolumn{3}{|c|}{ October } & \multicolumn{3}{|c|}{ November } & \multicolumn{3}{|c|}{ December } & \multicolumn{3}{|c|}{ January } \\
\hline $\mathrm{HCH}$ & G & $\mathrm{L}$ & $\mathrm{M}$ & G & $\mathrm{L}$ & M & G & $\mathrm{L}$ & $\mathrm{M}$ & G & $\mathrm{L}$ & $\mathrm{M}$ & G & $\mathrm{L}$ & $\mathrm{M}$ & G & $\mathrm{L}$ & $\mathrm{M}$ \\
\hline & $\mathrm{ND}$ & $\mathrm{ND}$ & ND & $\mathrm{ND}$ & $\mathrm{ND}$ & $\mathrm{ND}$ & ND & $\mathrm{ND}$ & ND & $\mathrm{ND}$ & $\mathrm{ND}$ & ND & $\mathrm{ND}$ & $\mathrm{ND}$ & $\mathrm{ND}$ & $\mathrm{ND}$ & $\mathrm{ND}$ & ND \\
\hline Aldrin & ND & $\mathrm{ND}$ & ND & $\mathrm{ND}$ & $\mathrm{ND}$ & $\mathrm{ND}$ & ND & $\mathrm{ND}$ & ND & $\mathrm{ND}$ & $\mathrm{ND}$ & ND & $\mathrm{ND}$ & $\mathrm{ND}$ & $\mathrm{ND}$ & $\mathrm{ND}$ & $\mathrm{ND}$ & ND \\
\hline Endosulfan & ND & $\mathrm{ND}$ & $\mathrm{ND}$ & $\mathrm{ND}$ & $\mathrm{ND}$ & $\mathrm{ND}$ & ND & $\mathrm{ND}$ & ND & $\mathrm{ND}$ & $\mathrm{ND}$ & ND & $\mathrm{ND}$ & $\mathrm{ND}$ & $\mathrm{ND}$ & $\mathrm{ND}$ & $\mathrm{ND}$ & $\mathrm{ND}$ \\
\hline DDT & ND & $\mathrm{ND}$ & ND & $\mathrm{ND}$ & $\mathrm{ND}$ & $\mathrm{ND}$ & ND & $\mathrm{ND}$ & ND & $\mathrm{ND}$ & ND & ND & $\mathrm{ND}$ & $\mathrm{ND}$ & $\mathrm{ND}$ & $\mathrm{ND}$ & $\mathrm{ND}$ & ND \\
\hline $2,4 \mathrm{D}$ & ND & $\mathrm{ND}$ & ND & $\mathrm{ND}$ & $\mathrm{ND}$ & ND & ND & $\mathrm{ND}$ & $\mathrm{ND}$ & $\mathrm{ND}$ & $\mathrm{ND}$ & ND & $\mathrm{ND}$ & $\mathrm{ND}$ & $\mathrm{ND}$ & $\mathrm{ND}$ & $\mathrm{ND}$ & ND \\
\hline Chloropyrifos & ND & $\mathrm{ND}$ & $\mathrm{ND}$ & $\mathrm{ND}$ & $\mathrm{ND}$ & $\mathrm{ND}$ & ND & $\mathrm{ND}$ & $\mathrm{ND}$ & $\mathrm{ND}$ & $\mathrm{ND}$ & ND & ND & $\mathrm{ND}$ & ND & $\mathrm{ND}$ & $\mathrm{ND}$ & $\mathrm{ND}$ \\
\hline Monocrotophos & $\mathrm{ND}$ & $\mathrm{ND}$ & $\mathrm{ND}$ & $\mathrm{ND}$ & $\mathrm{ND}$ & ND & ND & $\mathrm{ND}$ & $\mathrm{ND}$ & $\mathrm{ND}$ & ND & ND & $\mathrm{ND}$ & ND & $\mathrm{ND}$ & ND & $\mathrm{ND}$ & ND \\
\hline
\end{tabular}

During the present study, the pesticide likes $\mathrm{HCH}$, Aldrin, Endosulfan, DDT, 2,4 $\mathrm{D}$, Chloropyrifos and monocrotophos in water and fish samples were analyzed.The results showed that majority of pesticides were found to be below the detectable limit. No pesticides were detected from the site 2 Valiyazheekal and site 3 Kochiyude jetty (Table 2.2 and Table 2.3). The pesticide 2,
4 D was only recorded from the Ayiramthengu Site (Table 2.1) and found to be on September $(0.0008 \mathrm{mgl})$. Monocrotophos was detected from Choolatheruvu (Table 2.4) region during September $(0.0007 \mathrm{mgl})$ and October (0.0009 mgl).

Bioconcentration studies of the organophosphate and organochlorine 
pesticides in various tissues of Liza parsia and Etroplus suratensis were recorded in the (Table 2.5 and Table 2.6). There was no accumulation of organochlorine and organophosphate pesticide in various tissues of fish sample.

The present study distinguishes two main groups of pesticides depending on their occurrence and the range of accumulation detected, namely Organophosphate and Organochloride. In recent years, organophosphate and pyrethroid pesticides were widely used in agriculture field except organochlorine pesticides. These pesticides act on different species depending on age, weight and sex of animals ${ }^{6}$. It is clearly understood that most of the applied pesticides find their way too many other transport and conversion products. Thus they do not maintain at their target position but often reached into the environment through soil percolation, air drift or surface runoff affecting abundance and diversity of non target species producing complex effect on the ecosystem and altering tropics interactions (Rand et al., 1995).

DDT is also a banned pesticide, but it is a content of many other organochlorine insecticides. The presence of high concentration DDT might be attributed to slow degradation of DDT resulting in environmental persistence (Kim et al., 2007). The present study reported that there was no accumulation of DDT in water sample. Singh Leena et al., $2012^{11}$ reported the presence of DDT in water and sediments of Ganga River; it might be due to the discharge of medical waste from hospitals uses DDT for public health activites.

$\mathrm{HCH}$ is an organochlorine, also known as Lindane. Accumulation of Lindane was not in detectable limit observed at all the sampling sites during the entire study period. Sinha et al. ${ }^{10}$ reported that the presence of $\mathrm{HCH}$ and $\mathrm{BHC}$ in river water. WHO classifies lindane included in a Moderately Hazardous pesticide group. The primary use of lindane are to control a wide variety of insect pests in agricultural field, public health, and medicinal applications and also occur in the form of a suspension, emulsifiable concentrate, fumigant, seed treatment, wettable and dustable powder. The conspicuous absence of these sources of lindane in the premises of the water body could be the reason for the absence of lindane in the water and tissue samples of the study area. The USPEA ${ }^{12}$ has determined that lindane does not contaminate drinking water in excess of the Agency's level of concern.

Endosulfan includes a most toxic group pesticide class. In the environment, the endosulfan can be oxidized to the corresponding sulfate (endosulfan sulphate), which is persistent than its parents. Agnihotri et al. ${ }^{16}$ and Ghosh et al., (2000) reported that the presence of endosulfan in Ganga river water, this may be due to the extensive use of endosulphan in agricultural fields on the river banks, and also an organochlorine pesticide has the tendency to bioaccumulate in river sediments. It is a neurotoxic and an endocrine disruptor 
causing reproductive and developmental abnormalities in humans and animals. Fish is the main target victim of its bioaccumulation efficiency. The Insecticides Act of 1968 recommends restricted use of endosulfan. The Stockholm Convention, a global treaty to protect human health and environment from such chemical compounds, has declared endosulfan a persistent organic pollutant and 73 countries have banned its use. A handful of countries like India, China and Israel, however, oppose its ban (India still in endosulfan denial', Down To Earth, November 15, 2010) . TEAM, Editorial 2016 reported that The Kerala government has imposed a complete ban on the use of the pesticide endosulfan, which is alleged to have led to congenital deformities and even deaths in the state's Kasargod district. Endosulfan was used extensively as an aerial spray, including over the state's own cashew plantations. Aerial spraying in Kasargod was discontinued from 2004 under orders from the Pollution Control Board, Kerala. However, when tests in 2008-10 revealed the presence of the pesticide in water samples, aerial spraying was banned across the state. Therefore. the present study were found to be observed that Endosulphan was absent in water and fish samples of the study area during the entire study period.

Chlorpyrifos, comes under the class organophosphate insecticide and most widely used pesticide in the United States because it possesses a broad spectrum of activity against a wide range of arthropod and insect pests. The common name of Chlorpyrifos known as Dursb. Among all the OP insecticides, chlorpyrifos has the highest national agricultural usage. The result of the present study affirmed that the range of these pesticide in the water as well as tissue samples was below the detectable limit during the entire study period. This was in accordance with the findings of ${ }^{\mathbf{1 4}}$ who reported that chlorpyrifos indicated that concentrations less than $0.1 \mathrm{mg} / \mathrm{L}$ should not pose a risk to aquatic invertebrates in the North American aquatic ERA. Osman et $a l .{ }^{19}$, evidences that the moderate loading of chlorpyrifos was positively correlated to an agricultural area. However pesticides move offsite into surface waters through runoff, drainage or leachate ${ }^{17,20,21,23}$.

In India, monocrotophos mainly applied against cotton pests. Monocrotophos is still one of the most popular pesticides in the country, mainly because of its low price. Jacob Chandy ${ }^{\mathbf{1 8}}$ reported that among the organophosphate pesticides, monocrotophos is a major pesticide applied in Kuttanadu ,which is soluble in water and slightly soluble in mineral oil. During the present study, only at Site IV (Choolatheruvu) shows the presence of monocrotophos $(0.00006$ $0.0008 \mathrm{mg} / \mathrm{L}$ ), which is slightly above the detectable limit of the pesticide $(0.00005$ $\mathrm{mg} / \mathrm{L})$.

2, 4-D is an herbicide which is used to control broadleaf weeds on land and aquatic weeds. 2,4-D was present in the water samples collected during the months of September and October at site I 
(Ayiramthengu). Manigold and Schulze (1969) conducted an exhaustive study of pesticides in water was initiated in 1968 by the US Geological Survey, reported that the presence of DDT and its metabolites 2,4-D and 2,4,5-T. Some physicochemical parameters such as water hardness, which is the carbonate and bicarbonate concentration of water, When these compounds are present in high levels, they can reduce the efficiency of certain herbicides such as 2, 4-D. $\mathrm{pH}$ has a direct influence on the solubility of these pesticides in water body, the $\mathrm{pH}$ of the solution also can influence how long a pesticide molecule remains intact and the effect of $\mathrm{pH}$ usually proceeds faster as the temperature of the water increases ${ }^{\mathbf{1 1}}$. Chowdhury et al. ${ }^{34}$ reported that the Organophosphate and Carbamate pesticides were found to be in the Savar and Dhamrai Upazilas in Bangladesh, but in the present study reports there was no accumulation of Organophosphate and Carbamate pesticides in the Study area during the study period.

Fishes are used extensively for environmental monitoring because they take contaminants directly from water and diet ${ }^{28}$. Linko et al. ${ }^{29}$ pointed out that the level of bioaccumulation could fluctuate, that depending on the lipid content and feeding nature of the fish. Generally the ability of fish to metabolize organochlorine pesticide become moderate; therefore, contaminant loading in fish is reflective of the state of pollution in the surrounding environment ${ }^{24}$. The analysis pesticide such as $\mathrm{HCH}$, DDT,
2,4 D, aldrin, endosulfan, chlorpyrifos and monocrotophos in fish samples Liza parsia and Etroplus suratensis were collected from the four sites of the study area.

The level of BHC and DDT in fish samples was below detectable limit than the findings of Sarkar et al., (2003) in water and fish samples collected from both snow fed and rain fed rivers. Kumari et al. ${ }^{26}$, Kole et al. ${ }^{30}$ and Begum et al. ${ }^{27}$ reported that high concentration of $\mathrm{HCH}$ in fish samples from the river Gomti, Uttar Pradesh and fishes of Cauvery river, India. DDT metabolite likes p,p'-DDD and p,p'-DDE had significantly higher accumulation capacity in fishes. Metabolism of DDT in fish is generally accomplished through dechlorination to DDE but generally not to $\mathrm{DDD}^{31}$. Sethajintanin et al. ${ }^{32}$ and Yang et $a l .{ }^{33}$ have also reported that the dominance of p,p'-DDE in the fish samples. The present study there was no accumulation of DDT and its metabolites in fish samples.

The cyclodiene pesticides such as endosulfan and aldrin were also detected in the fish samples. The level of concentration of Aldrin was found to be very low in the present study compared to the report by Malik et al., (2007) in fish samples from Gomti river and Kumari et al. ${ }^{26}$ in Bihar. Pesticides like endosulfan is commonly used by fish cultivators to harvest their products, probably for minimizing the cost of harvesting. Thus there is probability of accumulation of pesticide residues in the fish tissue. Kerala State Biodiversity Board conducted a study about the contamination 
status of the rivers of Kerala using fish as an indicator were found to be observed that highest load of organochlorine pesticides present in Rasbora $s p$ followed by Danio $s p$ from Challakudy river, whereas residue levels were below detection limit in Puntius filamentous from Neyyar and Peruvamba, Garra mullya from Peruvamba and Valapattanam and Etroplus maculatus from Karamana. Endosulfan concentration in present study were below detectable limit than the levels reported by Kaur et al., (2008) in freshwater fishes of Punjab, Dhananjayan and Muralidharan ${ }^{25}$ in fishes of Karnataka, Kole et al. ${ }^{30}$ in Calcutta.

During the present study, the organophosphate pesticides such as, monocrotophos and chlorpyrifos were not detected in the fish samples collected from the study area. The present results with reference to chlorpyrifos is in accordance with Nasir Hafiz Zargar et al. ${ }^{37}$, who reported that among the organophosphate pesticides, chlorpyrifos were below detectable limit in fish samples collected from the different markets of Punchab. Concentration of Chlorpyrifos in present study was lower than the levels reported by Amaraneni $^{\mathbf{3 6}}$ in fish samples of Andhra Pradesh. The occurrence of pesticides was due to urban discharge to the tributaries, thus draining domestic wastes, industrial wastes and oil palm plantation effluents to the river, this could be the backflow of water due to tidal effects which can affect the streamflow (Wee et al., 2016). This may be due to the dilution from increased streamflow, causing contaminants to be transported away. Pesticide accumulations in surface waters also go around with strong seasonal patterns that result from the timing of pesticide applications and runoff conditions.

The results emerged from the present study will proved that there is no predominant use of pesticides in the study area, which as agricultural runoff or surface run off contributes to the negligible amount just above the detectable limit of pesticide concentration in water (ISGE, 1990). During the study period, all the sampling sites of the study area does not show a seasonal as well as site trend in the distribution pattern of pesticides. Studies on pesticide pollution in the above referred work reveals the absence of organochlorine and orgnophosphate residues in water bodies and fish samples collected from the study area. The decrease in the agriculture and the consequent reduction in the pesticides input could have been the reason for the low the level of pesticides both in the water samples and tissue samples of fishes.

\section{CONCLUSION}

The plethora of agitations against the pesticide use and awareness programs against the pollution in the state must have reduced the use of pesticides in the state. We find a positive correlation between the low to nil pesticide level with that people's awareness on the impact of pesticides. It is therefore concluded that fishes from the 
various study locations are fit for domestic consumptions, as the samples studied did not indicate any adverse or extremely high pesticide content that may affect the health of those consuming the fishes.

\section{REFERENCES}

1. Cerejeira, M.J., P. Viana, S. Batista, T. Pereira, E. Silva, M.J. Valero, A. Silva, M. Ferreria, M. Silva and A.M. Fernades, 2003. Pesticides in Portuguese surface and ground waters. Water Research 37:1055 -1063.

2. World Health Organization, 2004. The WHO recommended classification of pesticides by hazard and guidelines to classification. Geneva, Switzerland.

3. Beg, K.R. and S. Ali, 2008. Chemical contamination and toxicity of Ganga river sediment from up and down stream area at Kanpur, American Journal of environment sciences, (4), pp 362-366.

4. Afful, S., A.K. Anim and Y. Serfor-Armah, 2010. Spectrum of organochlorine pesticide Residues in fish samples from the Densu Basin. Res. J. Environ. Earth Sci., 2(3): 133138.

5. Metcaf, R.L., 1993. Pesticides in aquatic environment, In : Khan MAQ Khan (ed.) Pesticides in environment, Plenum press, New York, pp. 127.

6. Gill, T.S., J.C. Pant and J. Pant, 1988. Gill, Liver and Kidney Lesions associated with Environmental Exposure to Carbaryl and D.M. in the Fish, Puntius conchonius (Ham). Bull. Environ. Cotam. Toxicol., 41(1):71 78.

7. Rand, G.M., P.G. Wells and P.G. Mclarty, 1995. Introduction to aquatic toxicology, In: Rand G.M., Washington: Taylor and Francis, pp. 3-66.

8. APHA. Standard methods for the examination of waste water", 21st Edition. American Public Health Association and Water
Pollution Control Federation, Washington, DC, 2005.

9. AOAC International. Standard Methods for the analysis of Pesticide residuesin water and fish.21 st Edition, Association of Agricultural Chemist, 2012.

10. Sinha, A.K., R.K. Gopal and Krishna, 2001. Concentration of organochlorine pesticide residue in Ganga water in Bihar, India, Environmental and ecology, 19(2): 35-356.

11. Sing, Leena, S.K. Choudhary and P.K. Singh, 2012. Pesticide Concentration in water and sediment of River Ganga at selected sites in middle Ganga plain. International Journal of Environmental Sciences, 3: 260-274.

12. USEPA. Addendum to the 2002, Lindane Registration Eligibility Decision (RED), 2006.

13. Ghosh, Santanu, A.K. Das and K.K. Vass, 2000. DDT, $\mathrm{HCH}$ and Endosulfan residues in the lower stretches of river Ganga, Central Inland capture fisheries research institute, 27(4): 161-164.

14. Giesy, J.P., K.R. Solomon, J.R. Coats, K.R. Dixon, J.M. Giddings and E.E. Kenaga, 1999. Chlorpyrifos:

15. Ecological risk assessment in North American aquatic environments. Rev Environ Contam Toxicol., 160:1-129.

16. Agnihotri, N.P., G. Kulshresthra, V.T. Gajbhiye, S.P. Mohapatra and S.B. Singh, 1996. Organochlorine insecticide residues in agricultural soils of the Indo-Gangetic plain, Environment monitoring and assessment, 40(3): 279-288.

17. Larson, S.J., P.D. Capel and M.S. Majewski, 1997. Pesticides in surface waters: distribution, trends, and governing factors. Ann Arbor Press, Chelsea, pp. MI.

18. Jacob, Chandy, 2015. Ecotoxicological Studies of kuttanad wetland With Special Reference to Bioconcentration of Pesticides in Channa striatus (Bloch). Ph.D. Thesis submitted to University of Kerala. 
19. Osman, R., N. Saim, H. Juahir and M.P. Abdullah, 2012. Chemometric application in identifying sources of organic contaminants in Langat River Basin. Environmental Monitoring and Assessment, 184(2):10011014.doi: $10.1007 / \mathrm{s} 10661-011-2016-8$.

20. Armbrust, K.L., 2001. Chlorothalonil and chlorpyrifos degradation products in golf course leachate. Pest Management Science, 57(9):797-802.doi:10.1002/ps.361.

21. Nowell, L.H., P.D. Capel and P.D. Dileanis, 2010. Pesticides in stream sediment and aquatic biota: distribution, trends, and governing factors, 4, CRC Press, Boca Raton.

22. Kearns, C.A. and L. Prior, 2013. Toxic greens: a preliminary study on pesticide usage on golf courses in Northern Ireland and potential risks to golfers and the environment. In: Garzia F, Brebbia CA, Guarascio M (Eds) Safety and security engineering. V. WIT Press, Southampton, pp. 173-182

23. Tankiewicz, M., J. Fenik and M. Biziuk, 2010. Determination of organophosphorus and organonitrogen pesticides in water samples. TrAC Trend Analytical Chemistry 29(9):1050-1063. doi:10.1016/ j.trac.2010.05.008.

24. Gao, J., L. Liu, X. Liu, H. Zhou and J. Lu, 2009. The occurrence and spatial distribution of organophosphorous pesticides in Chinese surface water. Bulletin of Environmental Contamination and Toxicology, 82(2): 223229.

25. Sarkar, U.K., V.S. Basheer, A.K. Singh and S.M. Srivastava, 2003. Organochlorine pesticide residues in water and fish Samples: First report from rivers and streams of Kumaon Himalayan Region, India. Bulletin of Environmental and Contamination of Toxicology. 70(3): 485-493.

26. Kumari, A, R.K. Sinha and K. Gopal, 2001. Organochlorine contamination in the fish of the River Ganges, India. Aquatic Ecosystem Health and Management. 4(4): 505-510.

27. Begum, A., S. Hari Krishna and I.A. Khan, 2009.
Survey of persistent organochlorine pesticides residues in some Streams of the Cauvery River, Karnataka, India. International Journal of Chem Tech Research, 1: 237-244.

28. Lanfranchi, A.L., M.L. Miglioranza, K.S.B. Menone, L.J. Janiot, J.E. Aizpun and V.J. Moreno, 2006. Striped weakfish (Cynoscion guatucupa): a bio monitor of organochlorine pesticides in estuarine and near-coastal zones. Mar. Pollut. Bull., 52: 74-80.

29. Linko, R., J. Kalatharanta, P. Rantamaki and L. Eronen, 1974. Occurrence of DDT and PCB compounds in Baltic herring and Pick from the Turki archipelago, Environ. Pollut., 7: 193-207.

30. Kole, R.K., H. Banerjee and H. Bhattacharya, 2001. Monitoring of market fish samples for endosulfan and hexachlorcyclohexane residues in and around Calcutta. Bull Environ Contam Toxicol., 67:54-559.

31. Schmitt, C.J., J.L. Zajicek, T.W. May and D.F. Cowman, 1999. Organochlorine residues and elemental contaminants in US freshwater fish, 1976-1986. National Contaminant Biomonitoring Program. Review of Environmental Contamination and Toxicology. 162: 43-104.

32. Sethajintanin, D., E.R. Johnson, B.R. Loper and K.A. Anderson, 2004. Bioaccumulation profiles of chemical contaminants in fish from the lower Willamette river, Portland Harbour, Oregon. Archives of Environmental Contamination and Toxicology. 46(1): 114123.

33. Yang, R., T. Yao, B. Xu, G. Jiang and X. Xin, 2007. Accumulation features of organochlorine pesticides and heavy metals in fish from high mountain lakes and Lhasa River in the Tibetan Plateau. Environment International, 33: 151-156.

34. Choudhury, S.B. and R.C. Panigrahy, 1991. Seasonal distribution and behavior of Nutrients in the Greek and coastal waters of Gopalpur, East coast of India: MahasagarBulletin of the National Institute of Oeanography, 24(2):91-98. 
35. Dhananjayan, V. and S. Muralidharan, 2010. Organochlorine pesticides residues in inland wetland fishes of Karnataka, India and their implications on human dietary intake. Bulletin of Environmental Contamination and Toxicology. 85: 619-623.

36. Amaraneni, S.R., 2002. Persistence of pesticides in water, sediment and fish from fish farms in Kolleru Lake, India. Journal of the Science of food and agriculture, 82: 918-923.

37. Nasir Hafiz Zargar and Jatinder Paul Singh Gill, 2018. Studies on Levels of Pesticides Residues in Market Fish of Punjab (India). International Journal of Current Microbiol and Applied Sciences, 7(08): 2899-2905.

38. Avril, L. and P.K. Barten, 2007. Land use effects on streamflow and water quality in the northeastern United States. CRC Press, Boca Raton.

39. Sze, Yee Wee, Tuan Fauzan Tuan Omar, Ahmad Zaharin Aris and Yunho Lee, 2016. Surface
Water Organophosphorus Pesticides Concentration and Distribution in the Langat River, Selangor, Malaysia. Expo Health, 8:497-511.

40. Kerala State Biodiversity Board, 2010. Contamination Status of Rivers in Kerala : Fish as an indicator.

41. TEAM, Editorial, 2016. Kerala bans endosulfan after 500 deaths over 20 years. Indian Journal of Medical Ethics, [S.1.], 8(1).6.

42. Manigold, D.B. and J.A. Schulze, 1969. Pesticides in selected western streams - a progress report. Pesticide Monitoring J.3: 124 -135 .

43. ISGE, 1990. Integrated study of Ganga ecosystem between Kachla to Kannauj, Project report on Ganga, Dept. of nvironment, Ministry of environment and forest,Govt. of India, New Delhi. 